\title{
Studying Classical Archaeology and Ancient History in Sweden
}

\author{
Charlotte Scheffer
}

\begin{abstract}
This article traces the background and gradual growth of the subject of Classical Archaeology and Ancient History in Sweden from the $17^{\text {th }}$ century to the present day. As a university subject it grew out of the study of the realia in connection with the classical languages and was separated as an independent subject as late as 1909. Between the 1920s and the 1970s, large-scale excavations dominated most work. At present, the topics are more varied, better use is being made of the possibilities of the dual nature of the evidence of texts and archaeological material and there is a growing awareness of a new set of problems.
\end{abstract}

Charlotte Scheffer; Department of Classical Archaeology and Ancient History, Stockholm University, SE-106 91 Stockholm, Sweden.

The study of classical archaeology and ancient history as a university subject is of relatively recent date beginning with the creation of two chairs of Klassisk fornkunskap och antikens historia (Classical Archaeology and Ancient History) in Lund and Uppsala in 1909 (Brunnsåker 1976:23-27), which, of course, does not mean that important work on classical antiquities was not done before this time. A few examples will suffice. As early as the $17^{\text {th }}$ century, a classically-minded queen, Christina (1626-89), assembled a significant royal collection of antiquities, foraging all over Europe in order to complement the statues and objects brought to Sweden as spoils from the Thirty Years' War (Callmer 1954; Leander Touati 1998:23f). To further the study of antiquity, she invited to Uppsala University the Strasburg professor Johannes Schefferus (1621-79) (Brunnsåker $1976: 20 \mathrm{f})$. In the early $18^{\text {th }}$ century, an officer of Carl XII, Cornelius Loos (1686-1738), used the opportunity of the King's enforced stay in Bender to investigate Egypt and the Near East; among other places, he visited
Palmyra and made excellent drawings of its well-preserved ruins (Billig \& Billig 1981; Westholm 1985).

The person who played the most important part in the revived interest in antiquity that developed during the $18^{\text {th }}$ century was, however, King Gustaf III (1746-92). Like other young men of his time, he went on a slightly delayed, Grand Tour to Italy in 178485 , visiting Rome and Pompeii (Olausson 1998). With the help of Francesco Piranesi, the son of the great engraver, he started a new collection of antiquities, the old one having been sadly depleted by Queen Christina's departure for Rome in 1654 and the great fire in 1697. The antiquities were eventually, after the King's untimely death at a masquerade, exhibited to the general public in the Royal Palace in the museum that is still open today and known as Gustav III:s Antikmuseum (Leander Touati 1998). During King Gustaf's reign, the first Swedish excavation on classical soil took place, in the very Forum Romanum to which Swedish archaeologists have since returned in the $20^{\text {th }}$ 


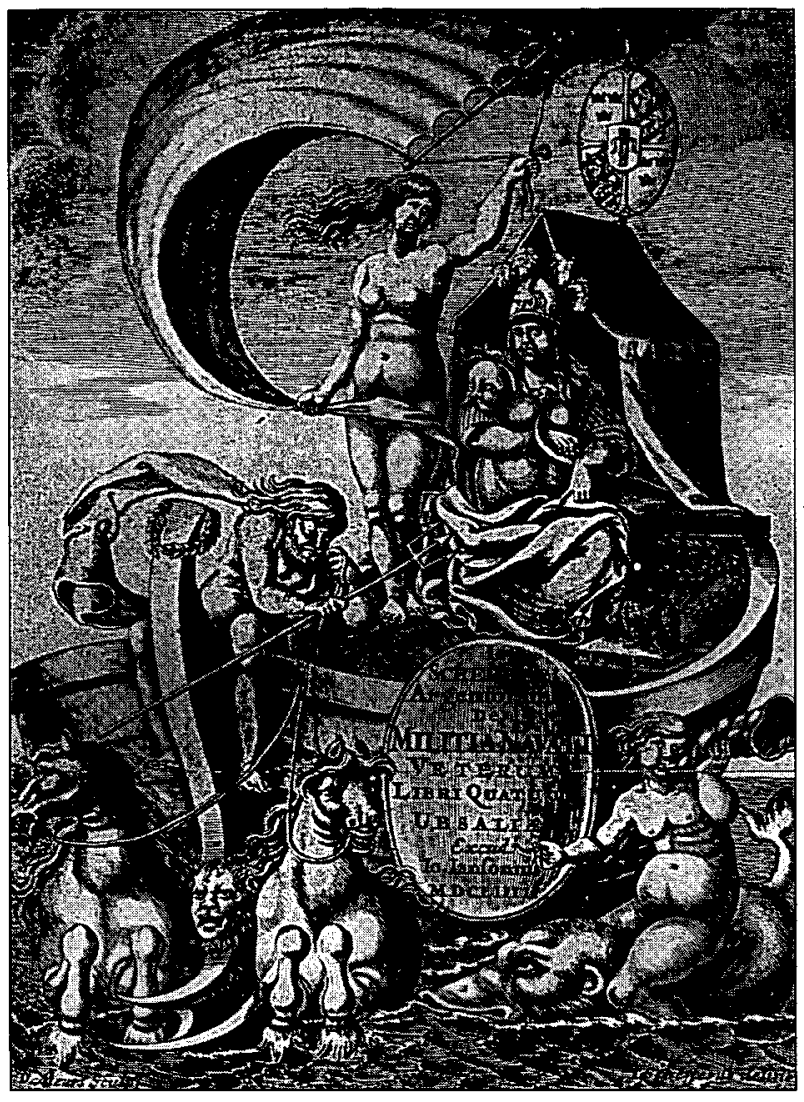

Fig. 1. One of the first books in the field of classical archaeology and ancient history to be published in Sweden, at Uppsala in 1654. Note the Swedish coat of arms crowning Athena's (Christina's?) tent. The book by J. Schefferus is about the naval warfare of the ancients.

century (Nylander 1989). The excavator was Carl Fredric Fredenheim (1748-1803), later to be the first keeper of the Royal Museum (Leander Touati 1998:49-51).

Meanwhile, the closest contact with the classical world was maintained through the classical languages. In Sweden, as in the rest of Europe, Latin was the language of the learned world, obligatory at all upper-school levels until the early $20^{\text {th }}$ century and for most university studies beyond the middle of the century. Most scholarly work in Classical Languages was concentrated on philological questions, and, although a few studies ac- tually dealt with the realia of the ancient world, the study of classical archaeology and ancient history was not at a level at all comparable to that of many other European countries. The Swedish Consul at Smyrna had at one point tried to interest the Swedes in starting an excavation in Pergamon, but, as the famous Swedish educationist, Julius Centerwall (1844-1923) expressed it, it was a good thing that this excavation never took place, not so much because of the expense as of the lack of a qualified director, classical archaeology in Sweden being then an almost unknown science (Centerwall 1888:372f; Åkerström 1973:8f).

In the second half of the $19^{\text {th }}$ century, an enormous amount of new information was brought to light through new, large-scale excavations based on a more scientific outlook. Several travellers from Sweden were inspired by the vastly increased archaeological material and the new ways of considering old problems that accompanied it. Contacts were established both with other European, mostly German, scholars and with the foreign institutes especially in Athens, and many young Swedish students were encouraged to go to mainly German universities. One of the most important travellers was Einar Löfstedt (1831-89), Professor of Greek at Uppsala, who visited Greece in 1876-77 and, on his return, lectured to audiences which included two young students who were later to become the first two professors of Klassisk fornkunskap och antikens historia at Uppsala, Sam Wide (1861-1918) and Lennart Kjellberg (1857-1936). Wide, energetic and with good contacts with several members of the German Institute at Athens, 
excavated with Dörpfeld on the west slope of the Acropolis, discussed in a letter to Centerwall the possibility of excavating in Crete or on Thera, as we now know excellent sites, or, as suggested to him by Dörpfeld, rather the Agora of Athens or the more insignificant sites of Kalaureia on Poros, Aphidna in Attica or Midea in the Argolis. He chose Kalaureia, which he excavated together with Kjellberg, and Aphidna (Callmer 1953; Nordquist forthcoming), bearing a large part of the expense himself; as he

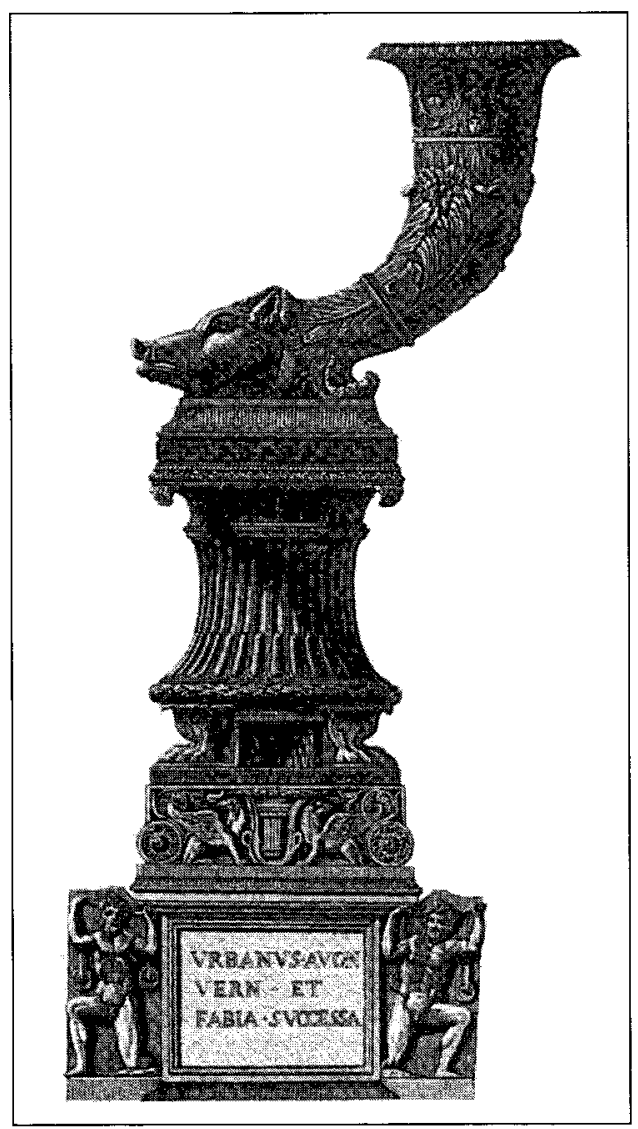

Fig. 2. A concoction of ancient - and new - fragments by Giovanni Piranesi (in his work Vasi, candelabri, cippi, sarcofagi, tripodi, lucerne ed ornamenti antichi, Rome 1778, Pl 91) bought by King Gustaf III as an authentic antique and now exhibited in the Medelhavsmuseet in Stockholm. wrote to Oscar Montelius (quoted in Åström 1980:9), it is easier to find money for something crazy such as dancing the cancan in the nude on Norrbro in Stockholm or searching for Noah's Ark on Ararat from a balloon than for a serious excavation (free translation from the Swedish). Midea, also, was later excavated by Swedish archaeologists.

The enthusiasm generated by individual scholars with an interest in classical antiquity combined with the enormous growth of knowledge produced by new excavations created a demand for studies of other aspects of classical antiquity than the purely philological. Also, the classical languages were losing importance. A reform in 1905, restricting the use of Latin in schools and, thus, lessening the necessity to educate a great number of schoolteachers, opened the way for the new subject. In 1909, the Swedish Parliament decided that the two associate professorships at Lund and Uppsala were to be transformed into chairs in Classical Archaeology and Ancient History (for a contribution to the debate, see Lundström 1898). The first two holders were Sam Wide (18611918) and Martin P:son Nilsson (1874-1967), the famous historian of Greek religion (Harrie 1934), who had been Wide's pupil during his time in Lund. A movable professorship, given to Axel Boëthius (1889-1969) in Gothenburg in 1935 (Lindberg \& Nilsson 1996:I:164f), was made permanent, and a fourth chair with a slightly different title was established in Stockholm in 1948, paid for by a subscription in honour of the centenary of the birth of Viktor Rydberg, an $19^{\text {th }}$-century writer with a profound classical knowledge. Among the contributors may be noted a well-known classical scholar and teacher in classical languages, Johan Bergman, whose radio lecture "Arvet från antiken" (The heritage from Antiquity) was published for the benefit of the subscription (Bergman 1928). Gösta Säflund (1903-) was appointed as the first holder of the chair (Inbjudan 1948). 


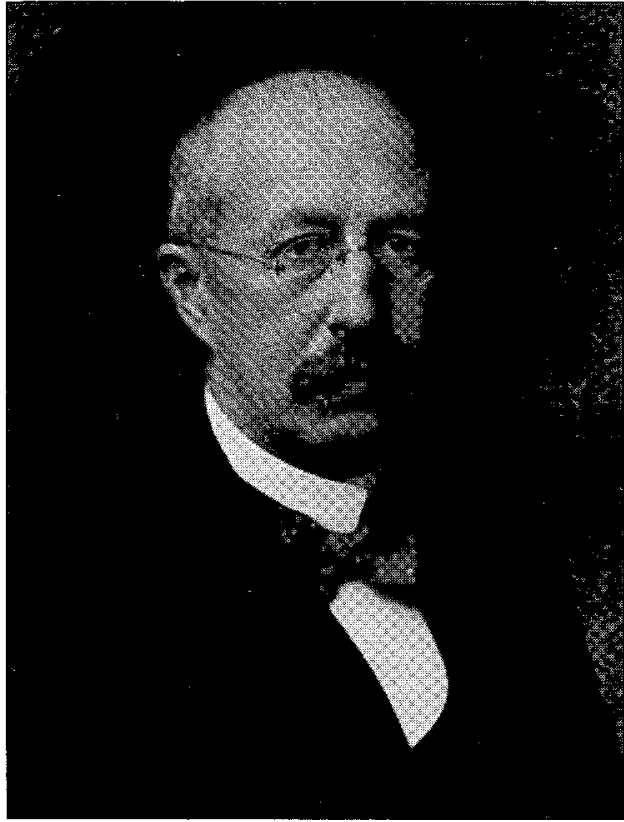

Fig. 3. Martin P:son Nilsson, the first Professor of Classical Archaeology and Ancient History at Lund, 1909-39. From the festschrift published on his retirement in 1939.

Of almost equal importance for the development of the subject was the decision to open an archaeological institute in Rome. Many had advocated the establishment of an institute at Athens, especially after the excavations of Asine started in 1922, with the support of the then Crown Prince, later King Gustaf VI Adolf (1882-1973). From 1898, however, Johan Bergman had given historical-archaeological summer courses in Rome, and in 1909, Wilhelm Lundström, Professor of Latin, had arranged for a course in Rome which was later discussed in a wider context (Bergman 1901; Lundström 1910; Förslag 1913). As an outcome of the discussions and on the initiative of the Crown Prince, an institute was inaugurated in Rome in 1926 (Boëthius 1960; Östenberg 1976). The first director was Axel Boëthius (Hanell 1949). It was more than twenty years before the institute in Athens became a reality in 1948. Its first permanent holder was $\AA$ ke
Åkerström (1902-91) (Åkerström 1973; Styrenius 1974; Wells forthcoming).

The new subject created in 1909 was given the title of Klassisk fornkunskap och antikens historia (Classical Archaeology and Ancient History) and even at that time it was extremely large and wide-ranging (Wikander 1986; Bergquist \& Gierow 1987:9-12). It included all aspects except the purely philological, spanned over an enormous period of time from the Palaeolithic to the end of Antiquity somewhere around A.D. 500 , i.e. both prehistory and history in all its aspects, and covered an area including all the lands that had at one time or another been touched by the Mediterranean cultures. The width and breadth of the subject seem to have been fairly original, subjects abroad being usually studied in separate parts, such as archaeology, art history, history, etc. It goes without saying that many of these aspects still await treatment in scholarly work or in teaching, but the opportunities exist. The most obvious division of the subject was into two parts, studies concerned with either textual or material evidence.

At first, naturally enough, as everybody who worked on the new subject had studied classical languages as their main subject, much early work was based on literary sources, but soon there was an about-turn. It almost seems as if the wish to put some distance between the new subject and the classical languages resulted in dissertations and other works being based almost exclusively on archaeological sources. This trend was further strengthened by the new excavations undertaken from the early 1920s at Asine (192230), Dendra (1926-39), Berbati (1935-38) and Asea (1936-38) and in Messenia (1926-36) and Cyprus (1927-31) (Styrenius 1974; Hägg forthcoming; Åström et al. 1994). These were the golden years of Swedish excavation in Greece and it is perhaps symptomatic that almost all these sites have been taken up again by the Swedes. In 1954, the Swedish part of the material found during the Swedish 
Cyprus Expedition became the nucleus of a new museum, the Medelhavsmuseet (Museum of Ancient and Near Eastern Antiquities) (Vessberg 1961; Styrenius 1994). After the war, again with the support of King Gustaf VI Adolf, excavations started in Etruria, the second important area of Swedish field investigation, at San Giovenale (1956-63), Luni sul Mignone (1960-63) and Acquarossa (1966-75) (Östenberg 1976:84-93, 98-100).

These excavations, and other smaller ones, encouraged generations of students to take up field archaeology and influenced the choice of subjects for much future work. It is not surprising that so many took the opportunity of going abroad and obtaining material that could be used as a point of departure for their dissertation and the possibility of writing it as a participant in an important archaeological project. Asine and Acquarossa have been the most successful projects in this respect. Of the permanent appointments at the four universities of Gothenburg, Lund, Stockholm and Uppsala, more than $50 \%$ are held at present by persons who have written dissertations or other important works based on material from Acquarossa or Asine.

The preponderance of archaeological and art-historical subjects has not failed to attract attention during the last few decades (Wikander 1984:91-97; Montgomery 1987:161, $165)$, especially since the study of the classical languages has tended towards more philological questions and, in the case of Latin, towards the later Latin that is perhaps more relevant for Sweden. I shall return to the question of the subjects chosen for dissertations shortly in dealing with the 102 dissertations written since 1909 , but first the reform of the universities in 1969 must be touched upon. It was intended to shorten the study time for doctorates and to make the studies more suitable to possible future occupations. The subject's title was changed; words such as klassisk and fornkunskap were considered to be antiquated and to emphasize the allegedly exclusive and unprofitable

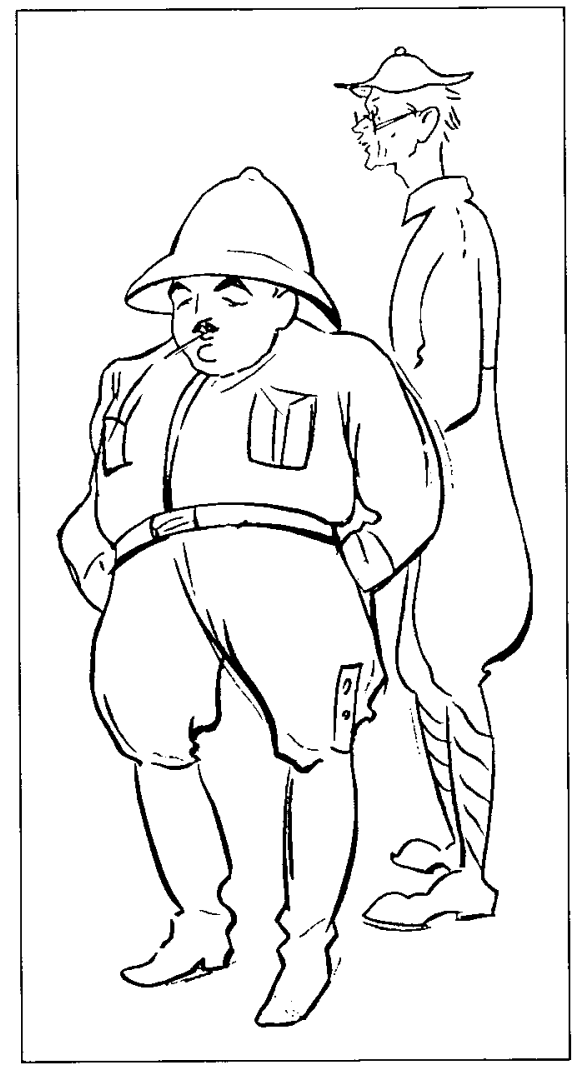

Fig. 4. The excavators of Asine, A.W. Persson, Professor of Classical Archaeology and Ancient History at Uppsala, 1924-5I, and O. Frödin, a Nordic archaeologist. Drawing by C.H.Jisen Carlsén. From Asine. De svenska utgrävningarna, published in 1931 by A.W. Persson.

character of the subject, which was therefore re-titled Antikens kultur och samhällsliv (Ancient Culture and Society) (Furumark 1984:5), a title more in tune with the modern, anti-elitist and anti-historical society in spite of the voices raised against the difficulty of identifying the subject with its counterparts abroad and of understanding what the subject actually was about at home (Lindberg \& Nilsson 1996:II:110f); in English, the old title has therefore been retained. Before this time, university credits in the classical languages were required; after the reform, only studies at school level - or none at all - were de- 
manded. The reform may now be said to have failed in some respects, though maybe not in all. The study time was not shortened and students were not better prepared for future professions. Previously most postgraduate students had been prepared for a school career, but afterwards, with this possibility no longer open because of the lack of languages, students tended to be mainly motivated by an interest in culture or antiquity in general.

When looking at the subjects chosen for dissertations during the ninety years between 1909 and 1999, it therefore seems profitable to divide the dissertations into two parts, those before 1970 and those from 1970 to the present, i.e. a first period of 60 years and a second of only 30 . A hundred and two dissertations have been publicly defended by members of seminars in Classical Archae-

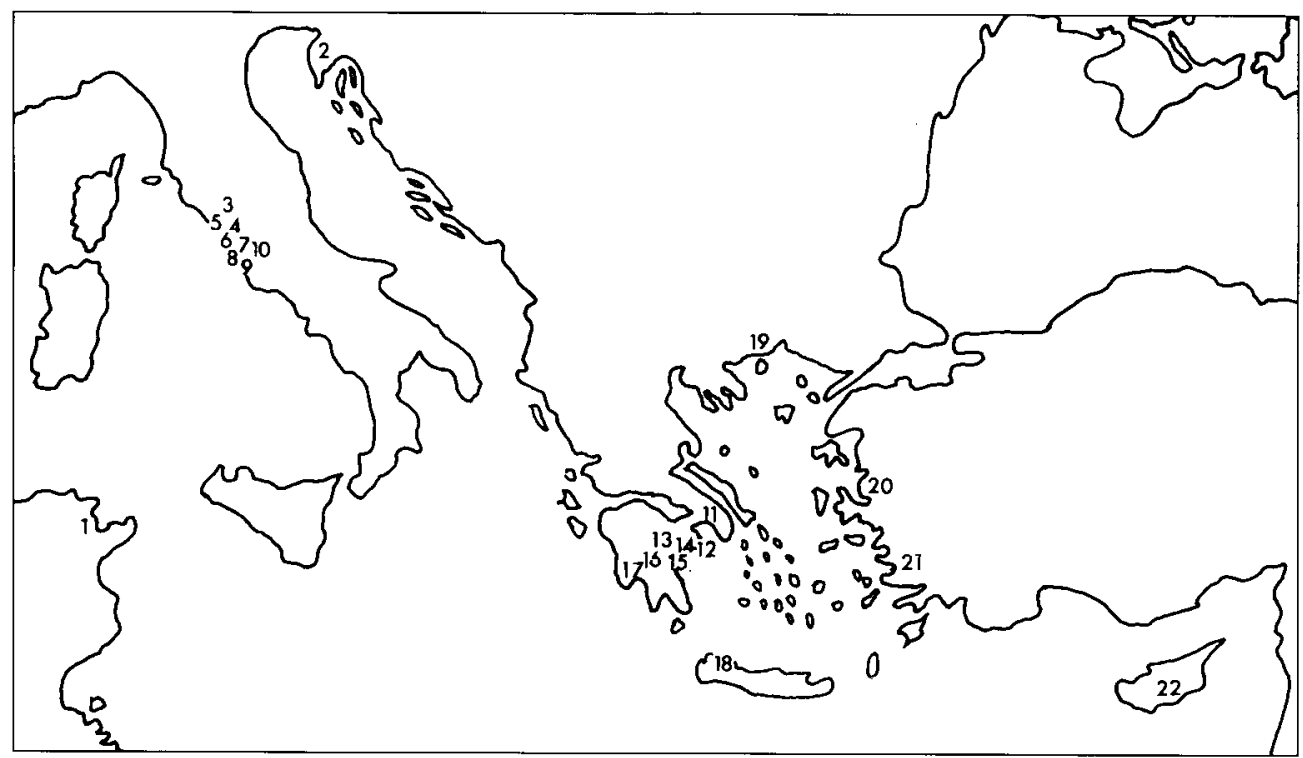

Fig. 5. Swedish excavations in the Mediterranean area between 1788-1999 with the exception of Egypt and the Near East. 1. Karthago 1979-80. 2. San Simone 1986-89. 3. Acquarossa1966-75, 1979, 1991. 4. Selvasecca 1965-71. 5. Luni sul Mignone 1960-63, 1989, 1992. 6. San Giovenale 1956-63. 1965, 1999. 7. Rom: 1788 (Forum Romanum, Basilica Julia), 1938-39, 1949, 1957, 1959, 1965, 196869 (mainly minor, check-up excavations), 1983-85 (Scandinavian excavation of the Temple of Castor in the Forum Romanum), 1993, 1995, 1998 (San Lorenzo in Lucina), 1996-99 (Prima Porta). 8. Nordic and Italian excavation at Ficana 1975-81. 9. Ardea 1929-35, 1952-53. 10. Nordic excavation at Nemi 1998- . 11. Aphidna 1894. 12. Kalaureia 1894, 1997, 1999. 13. Berbati 1935-38, 1953, 1959, 1994-95, 1997. 14. Dendra-Midea 1926-27, 1937, 1939, 1960, 1962-63, 1983-91, 1994- . 15. Asine 1922, 1924, 1926, 1930, 1970-74, 1976-78, 1985, 1989-90. 16. Asea 1936-38, 1997. 17. The Swedish Messenia Expedition 1926-27, 1929, 1933-34, 1936, 1952. 18. Chania 1970-84, 1987, 1989-90. 19. Paradeisos 1975-76. 20. Larisa 1902, 1932-34. 21. Labraunda 1948-51, 1953, 1960, 1988-89. 22. Cyprus. Minor explorations by Gjerstad 1924, the Swedish Cyprus Expedition 1927-31, Sinda 1947-48, Kalopsida and Agios Jakovos 1959, Hala Sultan Tekke 1971-. To the excavations above may be added the following surveys: Northern Istria 1990-91, Acquarossa 1989, area of Luni 1987-88 and 1990, the archaeological-historical study of drover's trails in southern Italy 1996, Berbati 1988-90 and 1999, Asea 1994-96, and the excavations of Pallantion and Tegea and the survey on Kephalonia undertaken by the Norwegians and Danes, respectively, under the cegis of the Swedish Institute. Map by the author partly based on map in Wikander 1986. 


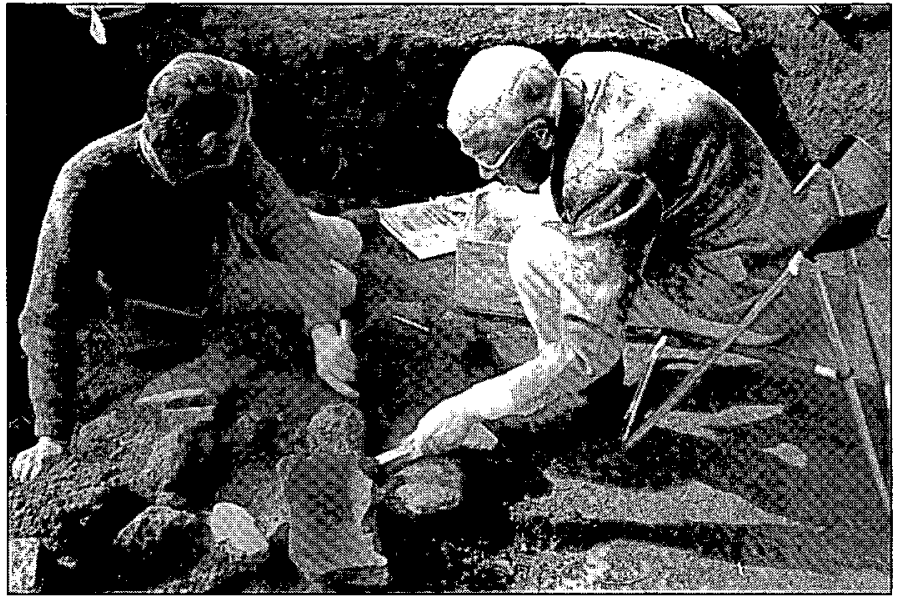

Fig. 6. Il re archeologo (the royal archaeologist) Gustaf VI Adolf excavating together with Roland Palsson, the former Custodian of Antiquities, at Acquarossa in 1972, shortly before the king's ninetieth birthday. Photo: D. Kuylenstierna.

ology and Ancient History. About a dozen others, which treated similar subjects but were defended as, for instance, dissertations in history, history of art, history of religion, Latin or Greek have not been included. The dissertations include 30 from Gothenburg, 29 from Lund, 13 from Stockholm and 30 from Uppsala. One doctor from Gothenburg, seven from Lund, two from Stockholm and sixteen from Uppsala became professors in Sweden. Thirty-four dissertations are from the first period which is twice as long as the second, but the later period has produced 68 , that is, exactly twice as many. From this, it is obvious that the influx of students was much greater during the second period. As this was accompanied by a vast increase in the number of undergraduates, about 10 or 15 times as many as in the 1960s, as well as in administrative duties, and did not lead to a corresponding increase in teaching posts, the consequence has been that most research is being done by postgraduate students and not by their professors, and the production has decreased (Wikander \& Wikander 1995:197).

Among the dissertations of both periods, the suspected preponderance of archaeological and art-historical subjects is a fact; about $30 \%$ of all dissertations can be said to be mainly based on literary, epigraphical or numismatic material. Of the 30 historical dissertations, 17 are from the first period and 13 from the second, and of the 13 , five are from the 1990s. Though historically-based dissertations have at no time formed a large part, the production seems steady enough and is even to some small extent increasing. Of the five dissertations from the 1990 s, one is based on Mycenaean material, three on Greek textual evidence and one on Roman Imperial material. With the decreased number of Swedish excavations in the 1980s followed a changed pattern in dissertation subjects, but it is also quite evident that the students nowadays who actually go in for classical languages do so more intensely and that some at least are becoming more and more aware of the possibility of combining the two parts of the subject.

Dissertations based on material from the prehistoric and historical periods (before and after 700 B.C., respectively) are in a ratio of $2: 3$. The eastern half of the Mediterranean is preferred in the ratio of roughly $2: 1$, if Magna Graecia is counted as West. No special schools are easily observable, not even more than a few followers of great professors such as Martin P:son Nilsson or Einar Gjerstad (1897-1988). The fairly strong element of Cypriote studies at Gothenburg must be due to Paul Åström (1929-), professor between 1969 and 1994 ( $\AA$ ström 1999); Gothenburg has relatively few historical dissertations, Lund only one after 1969 and Uppsala c. 47\% in all. Both at Gothenburg and at Uppsala, the eastern half of the Mediterranean world 
is much preferred. At Lund and Stockholm, the choice of areas is indifferent. It is probable that these preferences mirror the interests of the professors. At Gothenburg and Uppsala, the professors have been mainly or exclusively interested in the eastern half of the Mediterranean world, whereas at Lund and Stockholm, the interest has been more varied. It is also noticeable that, once their dissertations had been defended, many of the new doctors turned to subjects in completely different fields. The subjects of dissertations may be chosen and are chosen freely and individually at all the four departments. Given the archaeological bias, purely historical works are few and philosophical works are non-existent. Remarkably enough, the new trends in archaeology, although discussed among classical archaeologists, have left no wide, discernible influence in written work. Detailed, theoretical discussions are avoided, a trend which is, however, shared with most European classical archaeologists.

Furthermore, of the 102 dissertations, $58 \%$ were written by men and only $42 \%$ by women. The first woman to defend her dissertation was Birgitta Tamm (1930-92) of Stockholm University, in 1963. She was followed by three more women doctors during the 1960s. In the second period, however, the numbers changed: men wrote $43 \%$ of the dissertations and women $57 \%$. As a consequence, women at present predominate, but not much, in both teaching and research positions, with $55 \%$ against the $45 \%$ of men. Among the 74 postgraduate students, the tendency is exactly the same, $55 \%$ against $45 \%$. Twenty have their studies funded by their universities (19) or a foundation (1). In order to come to terms with the still long study times, a new reform was effected in 1998. Only students that are supported by the universities, a foundation or a permanent income may be accepted, on the general assumption that students who do not have to think about supporting themselves will be more dedicated and thus finish earlier. In this way, it is assumed that more students will finish their dissertations in shorter times, the approved time limit being four years. Since 1998 only two new postgraduate students have been accepted in all the four departments together.

The need of knowledge of foreign languages, besides Greek and Latin, may be one of the reasons for the long study times. Besides English, and depending on the chosen field of research, it may be necessary for the student to understand German, French, Italian, Modern Greek or some other language, at least to some degree. The dissertations are nowadays almost invariably written in English. All in all nearly three out of four (71) were written in English, the rest being divided between German (20), French (6), Swedish (3) and Italian (2). Most of the dissertations in German were, of course, written in the early part of the century when contacts with German classicists were close.

A further problem is the growth of new evidence and the number of pages written about it. That this is one of the reasons for the longer study time is self-evident, when

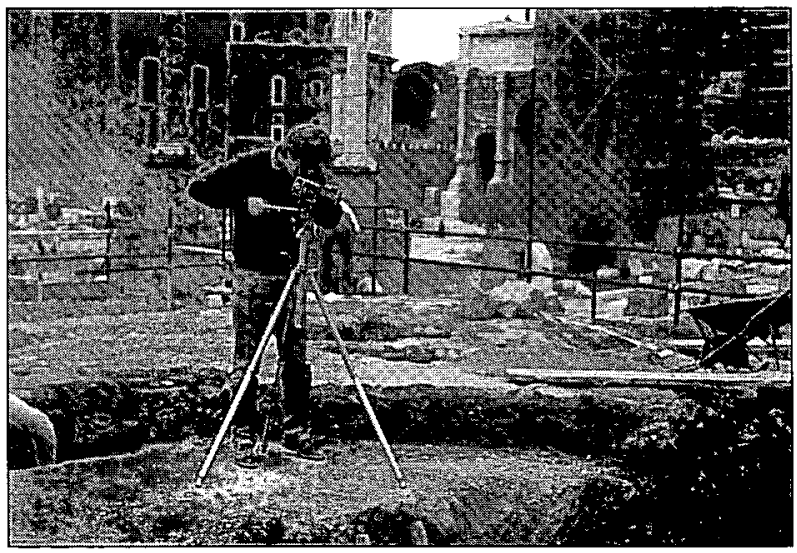

Fig. 7. Photographic documentation by a Swedish student during the Scandinavian excavation in the Forum Romanum in 1983. Photo: C. Gronne. 
one considers the ages at which dissertations have been defended. The oldest person so far was Albert Berg von Linde (1897-1986) who defended his thesis in Lund in 1979 at an age of nearly 82 . In the first period, only five defended their dissertations while still in their twenties: in Uppsala, Erik Holmberg (1907$97)$ at the age of 26 in 1933, Axel Boëthius in 1918, Einar Gjerstad in 1926 and Gösta Säflund in 1942, all at 29 years of age, and in Lund, Paul Åström at the age of 28 in 1957. In the second period, only one defended a dissertation at this early age: David Frankel, in 1974 at the age of 29 , one of a number of students of foreign nationalities invited by Professor Åström to finish their studies in Sweden. A division of the subject has therefore been discussed, chronologically into prehistoric and historical periods, geographically into areas such as East and West or according to type of evidence into history and archaeology. While allowing depth, this would unfailingly make for too small and narrow departments with a great risk of inbreeding.

The future of our subject, so glorious in the past, in spite of our small numbers and limited resources, is thus uncertain and problematical. The period of large-scale,
Swedish excavations in the Mediterranean countries is over, but excavation continues on a smaller scale, together with other nations or in the shape of surveys (cf. Medusa 1990:2; 1996:2). Hopeful aspects, contrary to the tendencies quoted above, are the new awareness of the enormous possibilities of combining the two types of evidence between which there should be no difference of purpose (Furumark 1984; cf. Andrén 1998, esp. 1-25), the new fields of research, and the new problems less concerned with groups of material and more with man's identity and place in society, and, finally, the importance of the heritage from the classical past and the questions of how it was - and is - perceived by posterity. An added stimulus is the growing interest in the historical past observable in society in general.

\section{English revised by Neil Tomkinson.}

\section{ACKNOWLEDGEMENTS}

I wish to thank all my colleagues in Antikens kultur och samhällsliv, past and present, and especially Brita Alroth, of Uppsala, Robin Hägg, of Gothenburg, and Örjan Wikander, of Lund. 


\section{REFERENCES}

Andrén, A. 1998. Between artifacts and texts. Historical archaeology in global perspective. New York \& London.

Bergman, J. 1901. De skandinaviska feriekurserna $i$ Rom, Neapel och Pompeji. En redogörelse och ett program. Stockholm

- 1928. Arvet från antiken. Ett radioföredrag. Säljes till förmån för Viktor Rydbergfonden vid Stockholms Högskola. Stockholm.

Bergquist, B. \& Gierow, P.G. 1987. Antikens kultur och samhällsliv. In: Wessman, Y. (Ed). Vetenskap idag. Lund. Pp. 9-25.

Billig, R. \& Billig. E. 1981. Medelhavsarkeologi i konungens och rikets tjänst. Två svenska forskningsfärder under stormaktstiden 1 . Medusa 1981:3. Pp. 14-25.

Boëthius, A. 1960. Svenska institutet $i$ Rom och Föreningen Svenska Rominstitutets Vänner under beskydd av H.M. Konungen. Malmö.

Brunnsåker, S. 1976. Classical Archaeology and Ancient History. In: Uppsala University 500 years. Faculty of Arts at Uppsala University. History and Philosophy. Acta Universitatis Upsaliensis. Pp. 19-33.

Callmer, Ch. 1953. Sam Wide und die ersten schwedischen Ausgrabungen in Griechenland. In: Opuscula Atheniensia 1. Skrifter utgivna av Svenska Institutet i Athen, 2. Lund. Pp. 208-233.

- 1954. Drottning Kristinas samlingar av antik konst Svenska Humanistiska Förbundet, 63. Stockholm.

Centerwall, J. 1888. Från Hellas och Levanten. Ströftåg till lands och vatten $i$ Grekland och Mindre Asien. Stockholm.

Furumark, A. 1984. Arkeologi och historia. Diskussionerna vid Seminariet för oldtidshistorie på Lysebu (Oslo) den 20 juni 1979. Hellenika 27. Pp. 3-7.

Förslag 1913. Förslag till svensk kurs i klassisk fornkunskap i Rom på uppdrag av Sektionen för klassiska språk vid Svenska filolog-och historikermötet $i$ Göteborg 1912 avgivet av utsedda kommitterade. Uppsala.

Hanell, K. 1949. Axel Boëthius och Svenska institutet i Rom. In: Festskrift tillägnad Axel Boëthius den 18 juli 1949 av Svensk-italienska föreningen. Göteborg. Pp. 49-52.

Harrie, I. 1934. Martin Persson Nilsson. Ord och Bild. Pp. 333-342.
Hägg, R. forthcoming. Swedish archaeology in Greece, 1894-1994. In: Peloponnesian sanctuaries and cults. Proceedings of the Ninth International Symposium at the Swedish Institute at Athens, 11-13 June 1994.

Inbjudan 1948. Viktor-Rydbergprofessuren i klassisk språkvetenskap och kulturforskning. In: Inbjudan till Stockholms högskolors minnesoch installationshögtidlighet $i$ stadshusets blä hall söndagen den 17 oktober $\mathrm{kl}$. 19. Stockholms högskolors rektorskonvent. Pp. 19-22.

Leander Touati, A.-M. 1998. Ancient sculptures in the Royal Museum. Skrifter utgivna av Svenska institutet $i$ Rom, 4\%, 55.

Lindberg, B. \& Nilsson, I. 1996. Göteborgs universitets historia. I. Pă högskolans tid. II. Ett växande universitet. Göteborg.

Lundström, W. 1898. Om innebörden av de e.o. professurerna i klassiska språk vid de svenska statsuniversiteten. Ett bidrag till en utredning. Upsala.

- 1910. Göteborgs Högskolas kurs i Rom. In: Göteborgs Högskolas Arsskrift 16:1. Pp. IXXI.

Medusa 1990:2. Aktuell svensk medelhavsarkeologi. Pp. 26-38.

Medusa 1996:2. Aktuella svenska arkeologiska utgrävningar i medelhavsområdet. Pp. 24-25.

Montgomery, H. 1987. Ancient history. In: Swedish Archaeology 1981-1985. Pp. 161-166.

Nordquist, G. forthcoming. A better time could not be found: Sam Wide and Lennart Kjellberg, pioneers of Swedish archaeology in Greece. In: Peloponnesian sanctuaries and cults. Proceedings of the ninth international symposium at the Swedish Institute at Athens, 11-13 June 1994.

Nylander, C. 1989. Svenskarna gräver i Roms hjärta. Populär arkeologi 1989:3. Pp. 26-27.

Olausson, M. 1998. The collector: Gustav III and his entourage. In: Leander Touati 1998. Pp. $37-47$

Styrenius, C.-G. 1974. Swedish Institute in Athens 1948-1973. Medelhavsmuseet Bulletin 9. Pp. $75-80$.

- 1994. From the Swedish Cyprus Expedition to the Medelhavsmuseet of today. In: Rydstedt, E. (Ed). The Swedish Cyprus Expedition. The living past. Medelhavsmuseet Memoir 9. Pp. 7-17. 
Vessberg, O. 1961. Medelhavsmuseet. Medelhavsmuseet Bulletin 1. Pp. 3-8.

Vestholm, A. 1985, Cornelius Loos. Teckningar från en expedition till Främre Orienten $1710-$ 1711. Nationalmuseums Skriftserie N.S. 6. Stockholm.

Wells, B. forthcoming. The prehistory of the Swedish Institute at Athens. Paper held on the 10 May, on the occasion of the celebrations of the fiftieth anniversary. In: New research on old material. Studies on material from the old Swedish excavations at Asine and Berbati in celebration of the fiftieth anniversary of the Swedish Institute at Athens. In Swedish in Hellenika 86, 1998. Pp. 5-11.

Wikander, Ö. 1984. Antikens fortlevnad i Sverige - en fråga om produktion. II. In: Antiken död eller levande. Skriftserie utgiven av vänföreningarna för de svenska instituten i Rom och Athen, 1. Uppsala. Pp. 87-100.

- 1986. Svensk arkeologisk forskning i Medelhavsvärlden. DIK-forum 15. Pp. 12-15. Re- printed as: Varför gräver svenskar vid Medelhavet. Populär arkeologi 1989:3. Pp. 8-9.

Wikander, Ch. \& Wikander, Ö. 1995. The archaeology of ancient Italy. Current Swedish Archaeology, Vol. 3. Pp. 197-206.

Åkerström, A. 1973. Svenska institutet i Athen. Ett jubileum och en återblick. Svenska spår och insatser i främmande land 7. Kungsbacka. A similar but earlier version from 1962 reprintet in Hellenika 63, 1993. Pp. 12-20.

Åström, P. 1980. Svenska utgrävningar i Medelhavsområdet. In: Arkeologiskt detektivarbete. SIMA, Pocket-book 11. Göteborg. Pp. 5-20.

- 1999. Cypriote archaeology in Göteborg. In: Cypriote archaeology in Göteborg. SIMA, Pocket-book 157. Pp 11-15.

Åström, P. et al. 1994. The fantastic years on Cyprus. The Swedish Cyprus Expedition and its members. Jonsered.

Östenberg, C.E. (Ed). 1976. Svenska institutet $i$ Rom 1926-1976. Viterbo.

\section{DISSERTATIONS}

Dissertations in Classical Archaeology and Ancient History 1909-1999. The list gives the original dissertation titles.

\section{GÖTEBORG}

1970. Marie-Louise Säflund, The east pediment of the temple of Zeus at Olympia. A reconstruction and interpretation of its composition.

1971. Gudrun Ahlberg, Prothesis and elphora in Greek Geometric art.

1973. Nikos Th. Nikolitsis, The battle of the Granicus, A source-critical study.

- Björn Olinder, Porticus Octavia in Circo Flaminio. Topographical studies in the campus region of Rome.

1974. David Frankel, Middle Cypriot White Painted pottery. An analytical study of the decoration.

1976. Charles M. Adelman, Cypro-Geometric pottery. Refinements in classification.
- Ino Michaelidou-Nikolaou, Prosopography of Ptolemaic Cyprus.

- Kyriakos Nikolaou, The historical topography of Kition.

1977. Britt Marie Fridh-Haneson, Le manteau symbolique. Etudes sur les couples votifs italiques en terre cuite.

1979. Lennart Hellbing, Alasia problems.

- Ulla Öbrink, Hala Sultan Tekke 6. A sherd deposit in Area 22.

1980. Peter M. Fischer, Applications of technical devices in archaeology. The use of $X$-rays, microscope, electrical and electro-magnetic devices and subsurface interface radar:

- Jane Johnson, Maroni de Chypre.

- Barbro Santillo Frizell, An early Mycenaean settlement at Asine. The late Helladic II B-III A: 1 pottery.

1983. Gunnel Hult, Bronze Age ashlar masonry 
in the eastern Mediterranean. Cyprus. Ugarit and neighbouring regions.

- Margareta Strandberg Olofsson, The head antefixes and relief plaques from Acquarossa. Part 1. A reconstruction of a terracotta decoration and its architectural setting.

- Karin Westerberg, Cypriote ships from the Bronze Age to c. $500 \mathrm{BC}$.

1992. Jeannette Forsén, The twilight of the Early Helladics. A study of the disturbances in eastcentral and southern Greece towards the end of the Early Bronze Age.

- Sophocles Hadjisavvas, Olive oil processing in Cyprus. From the Bronze Age to the Byzantine period.

- Lars Karlsson, Fortification towers and masonry techniques in the hegemony of Syracuse.

- Karin Niklasson, Early prehistoric burials in Cyprus.

- Michael Pettersson, Cults of Apollo at Sparta. The Hyakinthia, the Gymnopaideia and the Kaneia.

1993. Kathryn O. Eriksson, Red Lustrous Wheelmade Ware.

- Marianne Prohászka, Reflections from the dead. Metal finds from the Pantanello necropolis at Metaponto. A comprehensive study of grave goods from the 5 th to the $3 \mathrm{rd}$ centuries B.C.

- Anna-Greta Samuelson, Bronze Age White Painted I ware in Cyprus. A reinvestigation.

- Agneta Strömberg, Male or female? A methodological study of grave gifts as sex-indicators in Iron Age burials from Athens.

- Kjell Werner, The megaron during the Aegean and Anatolian Bronze Age. A study of occurrence, shape, architectural adaptation, and function.

1994. Inga Jacobsson, Aegyptiaca from Late Bronze Age Cyprus.

- Ann-Louise Schallin, Islands under influence. The Cyclades in the late Bronze Age and the nature of Mycenaean presence.

1999. Ingrid Werner, The Ivy Leaf Group.

\section{LUND}

1926. Ernst Kjellberg, Studien zu den attischen Reliefs des V. Jahrhunderts v. Chr.

1930. Natan Valmin, Etudes topographiques sur la Messénie ancienne.

1931. Harald Sjövall, Zeus im altgriechischen Hauskult.

1934. Krister Hanell, Megarische Studien.

1937 Erik Wikén, Die Kunde der Hellenen von dem Lande und den Völkern der Apenninenhalbinsel bis $300 v$. Chr, nebst einer Skizze des primitiven Weltbildes der Vorhellenen und der Hellenen.

1940. Arvid Andrén, Architectural terracottas from Etrusco-Italic temples.

1943. Christian Callmer, Studien zur Geschichte Arkadiens bis zur Gründung des arkadischen Bundes.

1952. Hilding Thylander, Étude sur l'épigraphie latine. Date des inscription. Noms et dénomination latine. Noms et origine des personnes.

1953. Erik Welin, Studien zur Topographie des Forum Romanu.

1957. Paul Åström, The Middle Cypriote Bronze Age.

1960. Bengt Thomasson, Die Statthalter der römischen Provinzen Nordafrikas von Augustus bis Diocletianus 1.

1966. Pär Göran Gierow, The Iron Age culture of Latium. Part 1. Classification and analysis.

1967. Carl Gustaf Styrenius, Submycenaean studies. Examinations of finds from mainland Greece with a chapter on Attic Protogeometric graves.

- Lena Åström, Studies in the arts and crafts of the late Cypriote bronze age.

1969. Jonas Crampa, Labraunda III:1. The Greek inscriptions. Part 1:1-12 (Period of Olympichus).

1970. Bengt Malcus, Le sénat et l'ordre sénatorial au bas-empire. Études.

- Sylvia Törnkvist, Arms, armour and dress of the terracotta statuettes from Ajia Irini, Cyprus. 
1971. Pontus Hellström, Labraunda. Pottery of Classical and later date, terracotta, lamps and glass.

1972. Paavo Roos, The rock tombs of Caunos. Part 1. The architecture.

1979. Albert Berg von Linde, Människan, vetet och kornet. Studier kring odlingens begynnelse. Arkeologi och genetik.

1980. Örjan Wikander, Vattenmöllor och möllare $i$ det romerska riket.

1983. Berit Wells, Asine II. Results of the excavations east of the acropolis 1970-74. Fasc. 4. The Protogeometric period. Part 2. An analysis of the settlement.

1987. Anne-Marie Leander Touati, The great Trajanic frieze. The study of a monument and the mechanisms of message transmission in Roman art.

1988. Charlotte Wikander, Acquarossa I. The painted architectural terracottas. Part 2. Typological and decorative analysis.

1990. Carole Gillis, Minoan conical cups. Form, function and significance.

- Ingela Wiman, Malstria-Malena. Metals and motifs in Etruscan mirror craft.

1995. Giordano Labud, Ricerche archeologicoambientali dell'Istria settentrionale. La valle del Fiume Risano.

1997. Charlotte Malmgren, Ficana. The Final Bronze and Early Iron Age.

1999. Martin Söderlind, The late Etruscan votive heads from Tessenanno. A study of production, distribution and sociohistorical context.

\section{STOCKHOLM}

1963. Birgitta Tamm, Auditorizm and palatium. A study on assembly-rooms in Roman palaces during the 1st century B.C. and the lst century A.D.

1969. Solveig Nordström, La céramique peinte ibérique de la province d'Alicante 1.

1972. Tullia Linders, Studies in the treasure records of Artemis Brauronia found in Athens.
- Ingrid Pohl, The Iron Age necropolis of Sorbo at Cerveteri.

1977. Erland Billig, Spätantike Architektur darstellungen 1.

1981. Charlotte Scheffer, Acquarossa II:1. Cooking and cookingstands in Italy 1400-400 B.C.

1983. Eva Rystedt, Acquarossa IV. Early Etruscan acroteria from Acquarossa and Poggio Civitate (Murlo).

1988. Kåre Fagerström, Greek Iron Age architecture. Developments through changing times.

- Lennart Lind, Romerska denarer funna $i$ Sverige.

1993. Cecilia Beer, Temple-boys. A study of Cypriote votive sculpture. Part 2. Functional analysis.

1994. Claude Björk, Early pottery in Greece. A technological and finctional analysis of the evidence from Neolithic Achilleion, Thessaly.

1997. Sven von Hofsten, The theme of the felineand-prey in Archaic Greek art. Classification - distribution - origin - iconographical context.

1999. Gunnel Ekroth, The sacrifial rituals of Greek hero-cults in the Archaic to the early Hellenistic period.

\section{UPPSALA}

1912. Erik Hedén, Homerische Götterstudien.

1918. Axel Boëthius, Die Pythaïs. Studien zur Geschichte der Verbindungen zwischen Athen und Delphi.

1926. Einar Gjerstad, Studies on prehistoric Cyprus.

1932. Gösta Säflund, Le mura di Roma repubblicana. Saggio di archeologia romana.

1933. Erik Holmberg, Zur Geschichte des cursus publicus.

- Hadar Lilliebjörn, Über religiöse Signierung in der Antike. Mit besonderer Berücksichtigung der Kreuzsignierung, nebst einem Exkurs über die Apokalypse und die Mithrasmonumente. 
1934. Åke Åkerström, Studien über die etruskischen Gräber unter besonderer Berücksichtigung der Entwicklung des Kammergrabes.

1935. Erland Ehnmark, The idea of God in Homer:

1937. Ulf Täckholm, Studien über den Bergbau der römischen Kaiserzeit.

1939. Arne Furumark, Studies in Aegean de-corative art. Antecedents and sources of the Mycenaean ceramic decoration.

1940. Erik Sjöqvist, Problems of the late Cypriote Bronze Age.

1941. Erik Gren, Kleinasien und der Ostbalkan in der wirtschaftlichen Entwicklung der römischen Kaiserzeit.

- Olof Vessberg, Studien zur Kunstgeschichte der römischen Republik.

1950. Bengt Hemberg, Die Kabiren.

1955. Sture Brunnsåker, The tyrant slayers of Kritios and Nesiotes.

1965. Hugo Montgomery, Gedanke und Tat. Zur Erzählungstechnik bei Herodot, Thukydides, Xenophon und Arrian.

1967. Birgitta Bergquist, The archaic Greek temenos. A study of structure and function.

1970. Carl Nylander, Ionians in Pasargadae. Studies in old Persian architecture

1973. Margareta Lindgren, The people of Pylos. Prosopographical and methodological studies in the Pylos archives. Part 2. The use of personal designations and their interpretation.
1974. Robin Hägg, Die Gräber der Argolis in submykenischer, protogeometrischer und geometrischer Zeit 1. Lage und Form der Gräber.

1976. Gisela Walberg, Kamares. A study of the character of palatial Middle Minoan pottery.

1987. Gullög Nordquist, A Middle Helladic village. Asine in the Argolid.

1988. Stig Forsberg, Near Eastern destruction datings as sources for Greek and Near Eastern Iron Age chronology. Archaeologicalhistorical studies 1. The cases of Samaria (722 B.C.) and Tarsus (696 B.C.).

1989. Brita Alroth, Greek gods and figurines. Aspects of the anthropomorphic dedications.

- Johan Flemberg, "Venus armata". Studien zur bewaffneten Aphrodite in der griechischrömischen Kunst.

1990. Kerstin Höghammar, Sculpture and society. A study of the interconnection between plastic art and society on Kos in the Hellenistic and Augustan periods.

1991. Mats Cullhed, Conservator urbis suae. Studies in the politics and propaganda of the emperor Maxentius.

- Jukka-Pekka Ruuskanen, Birds on Aegean Bronze Age seals. A study of representation.

1996. Peter Blomberg, On Corinthian iconography. The bridled winged horse and the helmeted female head in the sixth century $B C$.

1999. Hedvig Landenius-Enegren, The people of Knossos Prosopographical studies in the Knossos Linear B archives. 